\title{
Soluble Interleukin 2 Receptor Activity Measurement
}

National Cancer Institute

\section{Source}

National Cancer Institute. Soluble Interleukin 2 Receptor Activity Measurement. NCI

Thesaurus. Code C102280.

The determination of the amount of soluble interleukin 2 receptor activity present in a sample. 